\title{
Preparation, characterization and thermodynamic properties of Zr-containing Cl-bearing layered double hydroxides (LDHs)
}

\begin{abstract}
Zr-containing layered double hydroxides (LDHs) with variable $x \mathrm{Zr}_{\text {solid }}=\mathrm{Zr} /(\mathrm{Zr}+\mathrm{Al})$ mole fractions were synthesized by a co-precipitation method at ambient conditions. The chemical compositions of samples and corresponding aqueous solutions after syntheses were analyzed by ICP-OES, EDX ( $\mathrm{Mg}, \mathrm{Al}, \mathrm{Zr})$ and ion chromatography $\left(\mathrm{Cl}^{-}\right)$. Results of PXRD technique demonstrated that solids with $0 \leq x \mathrm{Zr}_{\text {solid }} \leq 0.5$ show only $\mathrm{X}$ ray reflexes typical for pure $\mathrm{LDH}$ compositions, while products of syntheses with $x \mathrm{Zr}_{\text {solid }}>0.5$ display additional patterns attributed to brucite. ICP-OES and EDX techniques shown that in pure $\mathrm{Zr}$-containing LDHs the $\mathrm{Mg} /(\mathrm{Al}+\mathrm{Zr})$ ratio is reducing with increase of $x \mathrm{Zr}_{\text {solid }}$ and the stoichiometry of brucite-like layers corresponds to $\left[\mathrm{Mg}_{3-2 \mathrm{x}} \mathrm{Al}_{1-\mathrm{x}} \mathrm{Zr}_{\mathrm{x}}\right]$. This fact may indicate that the incorporation of $1 \mathrm{Zr}$-containing specie results in the removal of $1 \mathrm{Al}-$ and $2 \mathrm{Mg}$-containing species from the pure Mg-Al-composition. Such mechanism may be confirmed by the observation that measured $a_{0}=b_{0}$ distances are generally consistent with theoretical estimates obtained from $\left[\mathrm{Mg}_{3-2 \mathrm{x}} \mathrm{Al}_{1-\mathrm{x}} \mathrm{Zr}_{\mathrm{x}}\right]$-stoichiometry. The presence of predominant $\mathrm{Mg}^{2+}, \mathrm{Al}(\mathrm{OH})_{4}^{-}$and $\mathrm{Zr}(\mathrm{OH})_{5}{ }^{-}$ complexes in aqueous solutions after syntheses was established in thermodynamic calculations by applying GEMS-Selektor v.3. code and, therefore, the reaction: $\mathrm{Mg}_{3} \mathrm{Al}_{1}(\mathrm{OH})_{8} \mathrm{Cl}_{1}+\mathrm{Zr}(\mathrm{OH})_{5}{ }^{-}=\mathrm{Mg}_{1} \mathrm{Zr}_{1}(\mathrm{OH})_{5} \mathrm{Cl}_{1}+$ $\mathrm{Al}(\mathrm{OH})_{4}^{-}+2 \mathrm{Mg}^{2+}+4 \mathrm{OH}^{-}$can describe a mechanism of $\mathrm{Zr}$-substitution. Estimates of the molar Gibbs free energies of $\mathrm{Zr}$-containing LDHs with $0 \leq x \mathrm{Zr}_{\text {solid }} \leq 0.5$ show that the incorporation of $\mathrm{Zr}$ into the $\mathrm{LDH}$ increasing significantly their aqueous solubility. Thus, it is not possible to neglect that $\mathrm{Zr}$ can be partly localized as $\mathrm{Zr}(\mathrm{OH})_{5}{ }^{-}$. ligands in the interlayer space of the LDH structure.
\end{abstract}

\footnotetext{
*Corresponding author: Konstantin Rozov, Institute of Energy and Climate Research (IEK-6) Nuclear Waste Management and Reactor Safety, Forschungszentrum Jülich, Germany, e-mail:k.rozov@fz-juelich.de

Hilde Curtius, Dirk Bosbach: Institute of Energy and Climate Research (IEK-6) Nuclear Waste Management and Reactor Safety, Forschungszentrum Jülich, Germany
}

Keywords: Solid solution, isostructural substitution, layered double hydroxides, thermodynamic modeling, anionic clays, hydrotalcites.

DOI 10.1515/ract-2014-2326

Received August 14, 2014; accepted November 13, 2014

\section{Introduction}

The disposal of radioactive waste materials at geological conditions requires the development of physically and chemically stable materials which will prevent the migration of various (i.e., cationic and anionic) radioactive compounds and their decay products from deep geological environments to the biosphere. Layered double hydroxides (LDHs) or hydrotalcite-like solids are of interest of these studies due to their unique properties to immobilize very wide range of cations (like, $\mathrm{Li}^{+}, \mathrm{Ba}^{2+}, \mathrm{Mg}^{2+}$, $\mathrm{Fe}^{2+}, \mathrm{Ni}^{2+}, \mathrm{Co}^{2+}, \mathrm{Eu}^{3+}, \mathrm{Fe}^{3+}, \mathrm{Cr}^{3+}, \mathrm{Ga}^{3+}, \mathrm{Sc}^{3+}, \mathrm{Zr}^{4+}$, etc.) [1-9] and especially due to their anion-exchange properties (substitution of $\mathrm{I}^{-}, \mathrm{Br}^{-}, \mathrm{Cl}^{-}, \mathrm{OH}^{-}, \mathrm{CO}_{3}{ }^{2-}$, $\mathrm{SO}_{4}{ }^{2-}, \mathrm{Fe}(\mathrm{CN})_{6}{ }^{4-}$, carboxylates, sulfonates or dicarboxylates $\mathrm{C}_{n} \mathrm{H}_{2 n}\left(\mathrm{CO}_{2}^{-}\right)_{2}$, etc.) [10-17]. The anion-exchange properties of LDHs are directly attributed with their structure consisting on positive charged octahedral brucitelike layers $\left[\mathrm{M}_{(1-\chi)}^{\mathrm{II}} \mathrm{M}_{(x)}^{\mathrm{III}}(\mathrm{OH})_{2}\right]^{\mathrm{x}+}$. The charge deficit of the octahedral layers is compensated by intercalated interlayer anions which are accompanied by molecules of water $\left[\mathrm{A}_{x / y}^{y} \cdot \mathrm{nH}_{2} \mathrm{O}\right]$. Therefore, LDHs can be considered as potential buffer materials for retention of mobile and hazardous anionic radionuclides (like, ${ }^{14} \mathrm{C},{ }^{129} \mathrm{I},{ }^{36} \mathrm{Cl}$, ${ }^{79} \mathrm{Se}, \mathrm{TcO}_{4}{ }^{-}$, etc.) [18]. At the present time the application of LDHs as anion-binding material is problematic task due to their chemical complexity when LDHs have to be considered as complex multicomponent solid solutions which thermodynamic, mixing and solubility properties are hardly achievable. Consequently, there is a problem to apply LDHs for geochemical modeling (partially at conditions of nuclear waste repositories). The present study is focused on the synthesis, characterization of a particular case of big LDH family, namely, chloride-bearing hydro- 
talcite (Htlc) $\mathrm{Mg}_{3} \mathrm{Al}(\mathrm{OH})_{8} \mathrm{Cl} \cdot n \mathrm{H}_{2} \mathrm{O}$ where the isostructural incorporation of $\mathrm{Zr}(\mathrm{IV})$ is expected. The selection of this system was based on the knowledge that similar Fecontaining LDHs were already identified as characteristic secondary phases when research nuclear fuel elements were in the contact with salt brine solutions under repository relevant conditions [5]. To investigate the incorporation of tetravalent cations into the $\mathrm{LDH}$ structure is interesting task because there is no clarity concerning incorporation of tetravalent metals in LDHs. Some of studies reported the possibility of synthesizing LDHs containing M(IV) ions [5, 19-24]. Another authors based on results of X-ray absorption spectroscopy (XAS) and Mössbauer spectroscopy [25] concluded that the M(IV) cations are segregated from LDH structure and may form amorphous M(IV) oxide-like particles. In our study the main reason to investigate the possibility of $\mathrm{Zr}$-containing $\mathrm{LDH}$ formation was the expectation that the incorporation of tetravalent cation has to affect on anion-exchange properties of LDHs due to the change of positive charge in brucite-like layers. Moreover, $\mathrm{Zr}(\mathrm{IV})$ can be considered as analogue of 4-valent actinides (i.e., $\mathrm{U}^{4+}$ and $\mathrm{Th}^{4+}$ ) and to investigate the behavior of zirconium is important task from point of view of geochemistry of nuclear waste repositories. Finally, $\mathrm{Zr}(\mathrm{IV})$ is an important constituent of nuclear waste repositories because it presented in cladding elements of nuclear fuel. Using various experimental techniques (X-ray powder diffraction, Raman spectroscopic measurements, scanning electron microscopy, energy dispersive Xray spectroscopy), the primary objective of this work was to explore the isostructural incorporation of $\mathrm{Zr}$ into the hydrotalcite structure (i.e., to proof the presence of solid solutions). The next objectives were: 1 ) to quantify stability properties (i.e., standard Gibbs free energies of formation) of $\mathrm{Zr}$-containing LDHs with the help of thermodynamic modeling [26, 27]; 2) to develop the provisional scheme of $\mathrm{Zr}$-substitution in the hydrotalcite structure.

\section{Experimental}

\subsection{LDH synthesis}

Samples of LDH solids with varying zirconium $x \mathrm{Zr}_{\text {solid }}=\mathrm{Zr} /(\mathrm{Zr}+\mathrm{Al})$ mole fractions were synthesized by a co-precipitation method at $T=25 \pm 2{ }^{\circ} \mathrm{C}$ and $\mathrm{pH}=10.00 \pm 0.05$. The synthesis procedure was based on the slow $(0.2-0.3 \mathrm{~mL} / \mathrm{min})$ addition of $40 \mathrm{~mL}$ degassed metal-chloride solution with $\mathrm{Mg} /(\mathrm{Al}+\mathrm{Zr})=3.0 \pm 0.1$ and desired $\mathrm{Zr} /(\mathrm{Zr}+\mathrm{Al})$ ratios into the reactor vessel containing $250 \mathrm{~mL}$ of boiled MilliQ water under stirring and under argon gas flow. The total concentration of $\mathrm{Mg}, \mathrm{Al}$ and $\mathrm{Zr}$ in metal-chloride solution was 0.8 moles/L. Simultaneously $2 \mathrm{M} \mathrm{NaOH}$ solution was added into the reactor by using an automated titrator 736 GP TITRINO in order to maintain $\mathrm{pH}=10.00 \pm 0.05$ constant. After the addition step, the stirring of suspension was continued for approximately $24 \mathrm{~h}$ under the controlled $\mathrm{pH}=10.00 \pm 0.05$. Then precipitate and supernatant liquid were separated by using $0.22 \mu \mathrm{m}$ MILLEX $^{\circledR}$ GP filters. The formed solid product was washed three times by boiled degassed MilliQ water and finally dried in a desiccator for $72 \mathrm{~h}$.

\subsection{Chemical analyses of solid and liquid phases}

The contents of $\mathrm{Mg}, \mathrm{Al}$ and $\mathrm{Zr}$ in the solids and aqueous solutions after syntheses have been determined by ICPOES method using TJA-IRIS ${ }^{\mathrm{TM}}$ instrument. The aqueous solutions after syntheses were analyzed after acidifying with approximately $0.5 \mathrm{~mL}$ of $8 \mathrm{M} \mathrm{HNO}_{3}$. Samples of solid phases were analyzed after dissolving in $2 \mathrm{M} \mathrm{HNO}_{3}$. Internal standard solutions were prepared from $\mathrm{MgCl}_{2} \cdot 6 \mathrm{H}_{2} \mathrm{O}$, $\mathrm{AlCl}_{3} \cdot 6 \mathrm{H}_{2} \mathrm{O}$ and $\mathrm{ZrOCl}_{2} \cdot 8 \mathrm{H}_{2} \mathrm{O}$ chemicals $\left(\right.$ Merck $^{\circledR}$ ).

\subsection{Photometric analyses}

Chloride anions in the product liquid phase and in synthesized solids were analyzed photometrically (spectrophotometer CADAS 100). The sample preparation and analysis procedure are described in details in [7].

\subsection{Powder X-ray diffraction}

The powder X-ray diffraction measurements were applied for structural characterization of synthesized solids. The patterns were recorded using $3003 \mathrm{TT}$ (General Electric ${ }^{\circledR}$ ) diffractometer (Bragg-Brentano geometry) at the ambient temperature within a $2 \theta$-range from 5 to $80^{\circ}$ with a step size of $0.02^{\circ} 2 \theta$ and a measuring time of $15 \mathrm{~s}$ per step. Unit-cell parameters $\left(a_{0}=b_{0}\right.$ and $\left.c_{0}\right)$ of pure $\mathrm{Zr}$-LDH solids have been estimated applying a Bragg-type equation and using relation between indexed $d_{h k l}$ distances and the lattice unit-cell parameters for hexagonal symmetry based on the first 4 reflections: (003), (006), (012), and (015). The scheme of these estimations is described in details previously [7, 28, 29]. 


\subsection{Raman spectroscopy}

Raman spectroscopic measurements have been carried out to identify the type of anion in the interlayer space of LDH structure. Raman scattering spectra were acquired using a LabRAM HR Vis ${ }^{\circledR}$ spectrometer equipped with $632.81 \mathrm{~nm}$ laser and recorded in wavenumber interval from 200 to $3800 \mathrm{~cm}^{-1}$. The spectra were calibrated using $\mathrm{Si}$ standard. The data were manipulated and recorded using LabSpec v.5. software. The band component analysis was carried out using "Fityk" (http://fityk.nieto.pl/) software, and the band fitting and smoothing were done using Gaussian functions.

\subsection{Scanning electron microscopy (SEM) and energy dispersive $X$-ray spectroscopy (EDX)}

The low-pressure scanning electron microscopy (SEM) was performed with Quanta $200{ }^{\circledR}$ microscope in order to investigate the morphology of synthesized crystallites. Examinations were performed at $70 \mathrm{~Pa}$. Analyses of solids $(\mathrm{Mg}$, $\mathrm{Al}, \mathrm{Zr}, \mathrm{O}, \mathrm{Cl}, \mathrm{C}, \mathrm{O}$ ) and the information about chemical homogeneity were performed with EDX spectroscopy by using Appolo X Silicon Drift Detector from $\mathrm{EDAX}^{\mathrm{TM}}$, at a voltage $20 \mathrm{kV}$.

\subsection{Thermodynamic modeling and estimation of Gibbs free energies}

The thermodynamic modeling has been performed assuming the thermodynamic equilibrium between precipitates and aqueous solutions after syntheses. This assumption was made based on previous results [29] which demonstrated that the degree of oversaturation in liquid phase after similar co-precipitation experiments is negligible and precipitates and corresponding aqueous solutions are at conditions which close to the equilibrium. The sequence of calculation steps needed for estimating Gibbs free energies of LDH solids was described in details before [7, 28, 29]. Firstly, by applying GEMS-Selektor v.3. code [26, 27] with built in Nagra-PSI thermodynamic database [18] and by using chemical analyses of aqueous solutions, the speciation of dissolved metals, activities and chemical potentials of relevant components (i.e., $\mathrm{Mg}^{2+}, \mathrm{Al}^{3+}, \mathrm{Zr}^{4+}, \mathrm{OH}^{-}$, $\mathrm{Cl}^{-}$) have been calculated. Then the statement which says that: "Gibbs free energy of the system at equilibrium is minimum, and chemical potentials of the components are the same at each phase" allowed to calculate the molar
Gibbs free energies from chemical potentials and from stoichiometric coefficients in Table 1 according to equation:

$$
\begin{aligned}
G_{\mathrm{f}}^{\circ}(\mathrm{LDH})= & a \cdot \mu\left(\mathrm{Mg}^{2+}\right)+b \cdot \mu\left(\mathrm{Al}^{3+}\right) \\
& +c \cdot \mu\left(\mathrm{Zr}^{4+}\right)+d \cdot \mu\left(\mathrm{OH}^{-}\right)+e \cdot \mu\left(\mathrm{Cl}^{-}\right)
\end{aligned}
$$

where $a-e$ : stoichiometric coefficients; $\mu$-calculated chemical potentials.

\section{Results}

\subsection{Compositions of solids and liquid phases after co-precipitation experiments}

Chemical compositions of pure Zr-containing LDHs and aqueous solutions after syntheses are provided in Tables 1 and 2 , respectively.

Results of chemical analyses demonstrated that each formula unit of Zr-bearing LDH contains $7.612 \pm 0.285$ $\mathrm{OH}^{-}$and $0.613 \pm 0.230 \mathrm{Cl}^{-}$. In addition we observed that washed solids contained only traces of $\mathrm{Na}$ (less than $1 \mathrm{wt} \%$ ), which means that the stoichiometric coefficient of sodium in solids was less than $\mathrm{Na}_{0.001}$. Table 1 reveals clearly that with the increase of the zirconium mole fraction $\left(x \mathrm{Zr}_{\text {solid }}\right)$ from 0.086 to 0.488 in synthesized solid the $\mathrm{Mg} /(\mathrm{Al}+\mathrm{Zr})$ cationic ratios reduces significantly (from 2.768 to 2.005$)$. It is necessary to remind that for all coprecipitation experiments the $\mathrm{Mg} /(\mathrm{Al}+\mathrm{Zr})$ ratio in initial metal-containing solutions always was fixed constant (3.0 \pm 0.1$)$. We observed that chemical compositions of synthesized solids are well described by $\left[\mathrm{Mg}_{3-2 \mathrm{x}} \mathrm{Al}_{1-\mathrm{x}} \mathrm{Zr}_{\mathrm{x}}\right]$ - stoichiometry, where $x$ - is the mole fraction of zirconium. The correctness of this statement has been additionally proofed by comparing measured $a_{0}=b_{0}$ unitcell distances in solids and those theoretical values obtained from regular octahedral brucite-like layers having $\left[\mathrm{Mg}_{3-2 \mathrm{x}} \mathrm{Al}_{1-\mathrm{x}} \mathrm{Zr}_{\mathrm{x}}\right]$-stoichiometry (see Section 3.2). Moreover, based on these stoichiometry variations it can be expected that the incorporation of $1 \mathrm{Zr}$-containing specie in to the pure $\mathrm{Mg}_{3} \mathrm{Al}_{1}(\mathrm{OH})_{8} \mathrm{Cl}_{1}$ composition results in removal of $2 \mathrm{Mg}$ - and $1 \mathrm{Al}$-containing species. In details this provisional scheme is described in Section 3.3. As seen in Table 2 measured concentrations of dissolved $\mathrm{Mg}, \mathrm{Cl}$ and $\mathrm{Na}$ are varying on the millimolal level (4.76-51.26, 180200, $157.69-190.49 \mathrm{mmol} / \mathrm{kg}$, respectively). At the same time concentrations of dissolved $\mathrm{Al}$ and $\mathrm{Zr}$ are lower than the detection limit of ICP-OES method. Therefore, for further modeling and for determining chemical potentials of $\mathrm{Al}^{3+}$ and $\mathrm{Zr}^{4+}$ species, the total dissolved molalities of 
Table 1: Stoichiometric formulae and estimated standard Gibbs free energies $\left(G_{f}^{o}\right)$ of formation of $\mathrm{Zr}$-containing LDHs synthesized at $T=25 \pm 2{ }^{\circ} \mathrm{C}$ and $\mathrm{pH}=10.00 \pm 0.05$.

\begin{tabular}{lrrr}
\hline $\begin{array}{l}\text { Chemical compositions of } \\
\text { "water-free" solids }\end{array}$ & $\begin{array}{r}\text { Mole fraction } \\
\text { of zirconium } \\
\text { in solid phase } \\
\left(x \mathrm{Zr}_{\text {solid }}\right)\end{array}$ & $\begin{array}{r}\mathrm{Mg} /(\mathrm{Al}+\mathrm{Zr}) \text { in } \\
\text { solid phase }\end{array}$ & $\begin{array}{r}\mathbf{G}_{\mathrm{f}}^{\circ} \text {, } \\
{[\mathrm{kJ} / \mathbf{m o l}]}\end{array}$ \\
\hline $\mathrm{Mg}_{2.768} \mathrm{Al}_{0.914} \mathrm{Zr}_{0.086} \mathrm{Cl}_{0.577}(\mathrm{OH})_{8.045}$ & 0.086 & 2.768 & -3459.41 \\
$\mathrm{Mg}_{2.681} \mathrm{Al}_{0.862} \mathrm{Zr}_{0.138} \mathrm{Cl}_{0.638}(\mathrm{OH})_{7.862}$ & 0.138 & 2.681 & -3387.37 \\
$\mathrm{Mg}_{2.662} \mathrm{Al}_{0.814} \mathrm{Zr}_{0.186} \mathrm{Cl}_{1.026}(\mathrm{OH})_{7.484}$ & 0.186 & 2.662 & -3384.78 \\
$\mathrm{Mg}_{2.410} \mathrm{Al}_{0.733} \mathrm{Zr}_{0.267} \mathrm{Cl}_{0.575}(\mathrm{OH})_{7.512}$ & 0.267 & 2.410 & -3222.86 \\
$\mathrm{Mg}_{2.527} \mathrm{Al}_{0.709} \mathrm{Zr}_{0.291} \mathrm{Cl}_{0.751}(\mathrm{OH})_{7.594}$ & 0.291 & 2.527 & -3320.76 \\
$\mathrm{Mg}_{2.326} \mathrm{Al}_{0.635} \mathrm{Zr}_{0.365} \mathrm{Cl}_{0.381}(\mathrm{OH})_{7.636}$ & 0.365 & 2.326 & -3193.11 \\
$\mathrm{Mg}_{2.005} \mathrm{Al}_{0.512} \mathrm{Zr}_{0.488} \mathrm{Cl}_{0.346}(\mathrm{OH})_{7.152}$ & 0.488 & 2.005 & -2971.14 \\
\hline
\end{tabular}

Table 2: Compositions of aqueous solutions $(\mathrm{pH}=10.00 \pm 0.05)$ after LDHs syntheses at $T=25 \pm 2{ }^{\circ} \mathrm{C}$.

\begin{tabular}{lrccccc}
\hline $\begin{array}{l}\text { Mole fraction of } \mathrm{Zr} \text { in } \\
\text { solids }\left(x \mathrm{Zr}_{\text {solid }}\right)\end{array}$ & $\mathrm{Mg}$ & \multicolumn{2}{c}{$\begin{array}{c}\mathrm{Cl} \\
{[\mathrm{mmol} / \mathrm{kg}]}\end{array}$} & $\mathrm{Na}$ & \multicolumn{2}{c}{$\begin{array}{c}\mathrm{Al} \\
{[\mu \mathrm{mol} / \mathrm{kg}]}\end{array}$} \\
\hline 0.086 & 4.76 & 199.00 & 184.76 & 1.14 & 0.51 \\
0.138 & 51.26 & 192.00 & 190.49 & 1.14 & 0.51 \\
0.186 & 7.01 & 180.00 & 169.19 & 1.10 & 0.54 \\
0.267 & 8.60 & 200.00 & 174.33 & 1.14 & 0.51 \\
0.291 & 8.27 & 191.00 & 177.07 & 1.14 & 0.51 \\
0.365 & 14.95 & 195.00 & 169.48 & 1.10 & 0.54 \\
0.488 & 19.40 & 187.00 & 157.69 & 1.10 & 0.54 \\
\hline
\end{tabular}

these metals were assumed to be on the level 1.10-1.14 and $0.51-0.54 \mu \mathrm{mol} / \mathrm{kg}$, respectively (i.e., detection limit of ICP-OES for these metals). In conclusion we see that the ionic strength $(\sim 0.2 \mathrm{M})$ of all "syntheses solutions" is generally defined by sodium concentrations and this fact permitted the use Davies model [30] for estimating activities and chemical potentials of relevant dissolved components.

\subsection{Characterization of synthesized solids by PXRD, Raman spectroscopy, SEM and EDX techniques}

PXRD technique has been used in order to proof that synthesized solids are indeed pure $\mathrm{Zr}$-containing hydrotalcite-like solids and, thereby, to check that $\mathrm{Zr}$ is structurally incorporated in the LDHs. Moreover, PXRD approach could be applied to construct the provisional scheme of $\mathrm{Zr}$ incorporation into the structure of hydrotalcite-like solids.

We observed that precipitates with the mole fraction of zirconium with $0 \leq x \mathrm{Zr}_{\text {solid }} \leq 0.5$ display only $\mathrm{X}$-ray pat- terns (Figure 1a) typical for pure hydrotalcite-like solids. The increase of $x \mathrm{Zr}_{\text {solid }}$ in pure LDH solids is accompanied with the widening of X-ray reflexes and, therefore, may indicate on: (1) the decrease of crystallite size in solids, or (2) the presence of undetectable amorphous substance (for instance, brucite). The second hypothesis is confirmed by the fact that the background of diffractogramms (Figure 1a) is continuously climbing with the growth of $x \mathrm{Zr}_{\text {solid }}$. In synthesized phases with $x \mathrm{Zr}_{\text {solid }}>$ 0.5 we observed additional X-ray reflexes attributed to brucite (see light-gray circles on Figure $1 b$ ).

Evaluated unit-cell parameters $a_{0}=b_{0}$ reflex intermetallic distances in octahedral brucite-like layers in the LDH structure and shown as a function zirconium content $\left(x \mathrm{Zr}_{\text {solid }}\right)$ (Figure 2a) and as a function of $\mathrm{Mg} /(\mathrm{Al}+\mathrm{Zr}$ ) cationic ratio (Figure 2b). As seen on Figure 2, $a_{0}=b_{0}$ unit-cell distances are generally correlating with these compositional changes. Moreover, the theoretical values of $a_{0}=b_{0}$ unit-cell parameters were calculated based on the regular brucite-like layers having $\left[\mathrm{Mg}_{3-2 \mathrm{x}} \mathrm{Al}_{1-\mathrm{x}} \mathrm{Zr}_{\mathrm{x}}\right]$ stoichiometry (where ionic radii of cations in octahedral coordination are $\mathrm{r}_{\mathrm{Mg}^{2+}}=0.720 \AA \mathrm{A}_{\mathrm{A}^{3+}}=0.535 \AA$, $\mathrm{r}_{\mathrm{Zr}^{4+}}=0.720 \AA$ ) [31]. Figure 2 is demonstrating that theoretical dependences of $a_{0}=b_{0}$ (solid curves) are generally consistent with experimental values. Therefore, this fact can indicate that $\left[\mathrm{Mg}_{3-2 \mathrm{x}} \mathrm{Al}_{1-\mathrm{x}} \mathrm{Zr}_{\mathrm{x}}\right]$-stoichiometry may describe the variety of chemical compositions of precipitates. Moreover, this chemical variability is pointing out on ont the situation when the incorporation of $1 \mathrm{Zr}$-specie into the hydrotalcite $\mathrm{Mg}_{3} \mathrm{Al}_{1}(\mathrm{OH})_{8} \mathrm{Cl}_{1}$ structure replaces $2 \mathrm{Mg}$ - and $1 \mathrm{Al}$-containing species. Nevertheless, the structural position of $\mathrm{Zr}$ in LDH solids is still questionable because of the big scatter of measured $a_{0}=b_{0}$ values. The clarifying of the structural position of $\mathrm{Zr}$ in the LDH is complicated by the presence in $\mathrm{Zr}$-bearing precipitates of unidentified amorphous phase. 

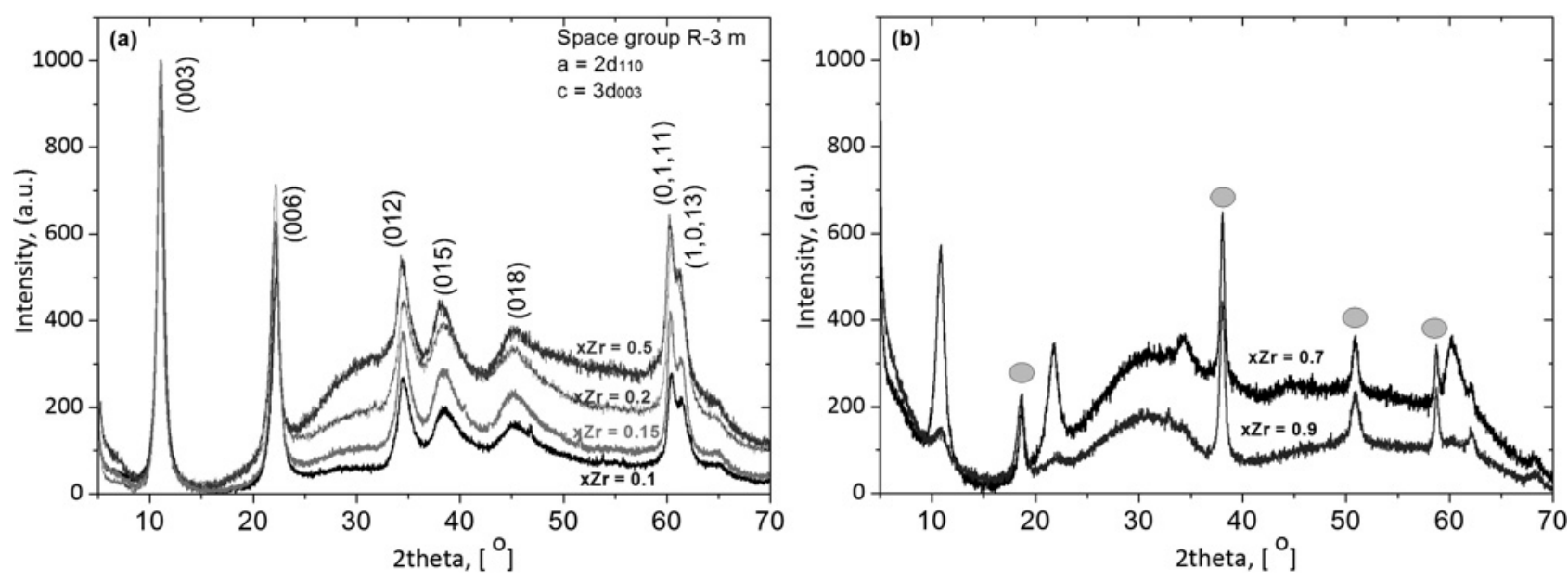

Fig. 1: X-ray diffractograms of Zr-containing LDHs: (a) with $x \mathrm{Zr}_{\text {solid }} \leq 0.5$; and (b) with $x \mathrm{Zr}_{\text {solid }}>0.5$ (light-gray circles correspond to patterns attributed to brucite).
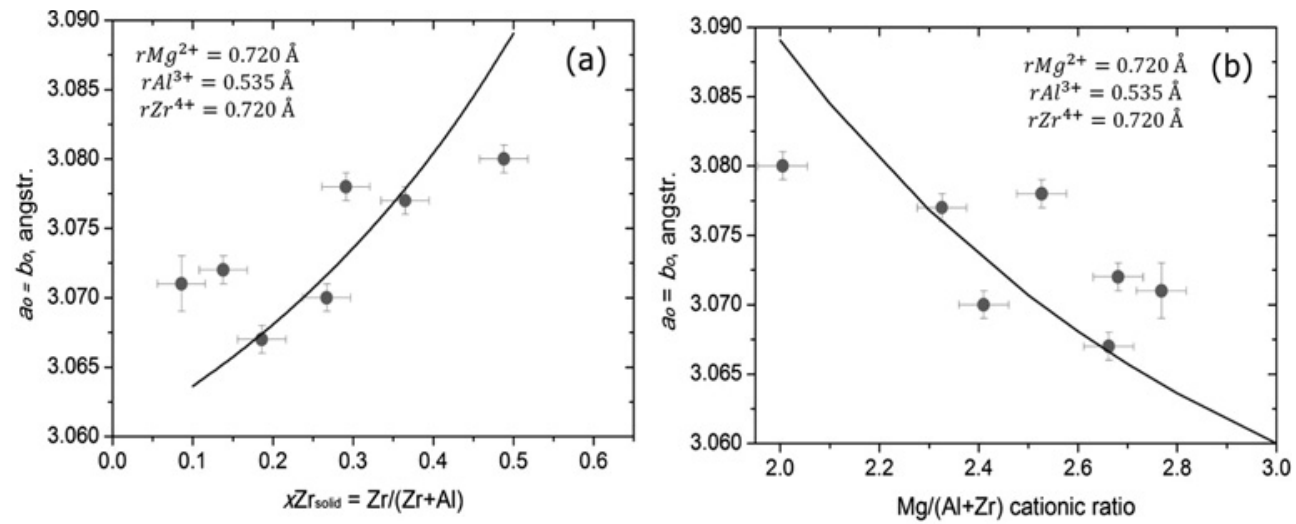

Fig. 2: Unit-cell distances $a_{o}=b_{o}$ as a function of $\mathrm{Zr} /(\mathrm{Al}+\mathrm{Mg})$ the zirconium mole fraction (a) and as a function of $\mathrm{Mg} /(\mathrm{Al}+\mathrm{Zr})$ cationic ratio (b) in synthesized LDHs. Solid curves represent theoretical estimates based on the regular octahedral brucite-like layers having $\left[\mathrm{Mg}_{3-2 \mathrm{x}} \mathrm{Al}_{1-\mathrm{x}} \mathrm{Zr}_{\mathrm{x}}\right]$ - stoichiometry.
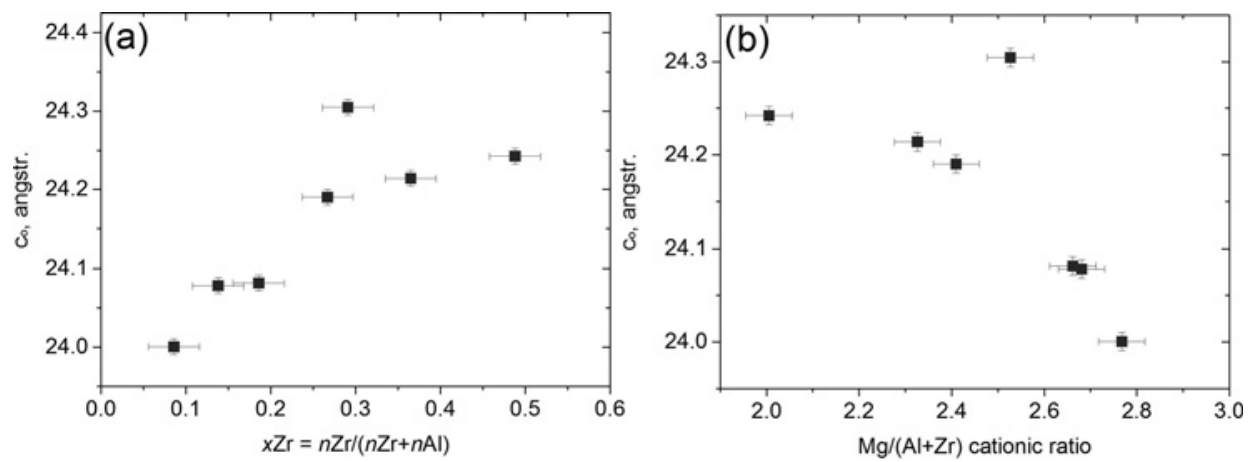

Fig. 3: Unit-cell parameter $c_{o}$ as a function of $\mathrm{Zr} /(\mathrm{Al}+\mathrm{Mg})$ the zirconium mole fraction (a) and as a function of $\mathrm{Mg} /(\mathrm{Al}+\mathrm{Zr})$ cationic ratio (b) in synthesized LDHs.

Unit-cell parameters $c_{0}$ of pure $\mathrm{Zr}$-LDH solids as a function of $x \mathrm{Zr}_{\text {solid }}$ mole fraction and as a function of $\mathrm{Mg} /(\mathrm{Al}+\mathrm{Zr})$ cationic ratio are shown on Figure $3 \mathrm{a}$ and $\mathrm{b}$, respectively.
As seen on Figure $3 a$ and $b$ the increase of unit-cell parameter $c_{0}$ is related with the growth of $\mathrm{Zr}$-content (and corresponding decrease of $\mathrm{Mg} /(\mathrm{Al}+\mathrm{Zr})$ ratio) in synthesized solids. At first sight this observation is in the contra- 
diction with the solid stoichiometry variations presented in Table 1. The reason is that unit-cell parameter $c_{0}$ reflexes mainly changes in the size of the interlayer space of the LDH structure. Therefore, the unit-cell parameter $c_{0}$ has to be a very sensitive to compositional changes of the interlayer (content of water, hydroxyl groups, chloride ions). From Table 1 it is clearly seen that there is the decrease of $\mathrm{OH}^{-}$- and $\mathrm{Cl}^{-}$-contents in LDHs with the growth of $x \mathrm{Zr}_{\text {solid }}$ values. Consequently, it is expected that $c_{0}$-value should decrease with the growth of $\mathrm{Zr}$-content. The opposite observation should indicate that: (1) amount of structural water-molecules can increase with growth of $\mathrm{Zr}$-content or (2) there is a substitution of $\mathrm{Zr}$-species in the interlayer space of LDH structure. The first explanation is doubtful because we demonstrated that in all solids the watercontent is approximately constant (2.33-2.50 molecules). Therefore, it is necessary to consider the hypothesis which implies the possibility of partial $\mathrm{Zr}$-substitution into the interlayer space. The structural position of $\mathrm{Zr}$-atoms in LDHs may be elaborated by applying different approaches. Particularly, the Rietveld structural refinements would help to specify the structural rearrangements of $\mathrm{Zr}$ in the LDH structure. However, at the present study these refine- ments were not performed because of the poor crystallinity of synthesized precipitates. Consequently, we were focused on other available approaches to identify the coordination environment of $\mathrm{Zr}$ in the LDH structure (i.e., thermodynamic modeling with GEMS-Selektor v.3. code) (see Section 3.3).

Raman spectroscopy has been used as suitable method for identifying the nature of the interlayer anions. Raman bands (around 467, 546, 1060, 3450 and $3700 \mathrm{~cm}^{-1}$ ) which are typical for hydrotalcite-like solids [32] have been observed. Typical Raman spectra of synthesized LDHs with $x \mathrm{Zr}_{\text {solid }} \approx 0.10$ are displayed on Figure 4. The band detected around $467 \mathrm{~cm}^{-1}$ is unique for hydrotalcite-like solids and assigned to the Me-O-Me linkage bonding [33]. The band around $546 \mathrm{~cm}^{-1}$ is presented in all Raman spectra of synthesized $\mathrm{Zr}$-containing LDHs and according to [32] originates from the interlayer carbonate-water unit, where two hydrogen atoms of $\mathrm{H}_{2} \mathrm{O}$ molecule are interacting with two oxygen atoms of carbonate-anion, strongly indicating the presence of carbonate in the system. The presence of carbonate in precipitates is explained by a very significant affinity of this anion to LDH phases. Carbonate can be contaminated during the synthesis procedure
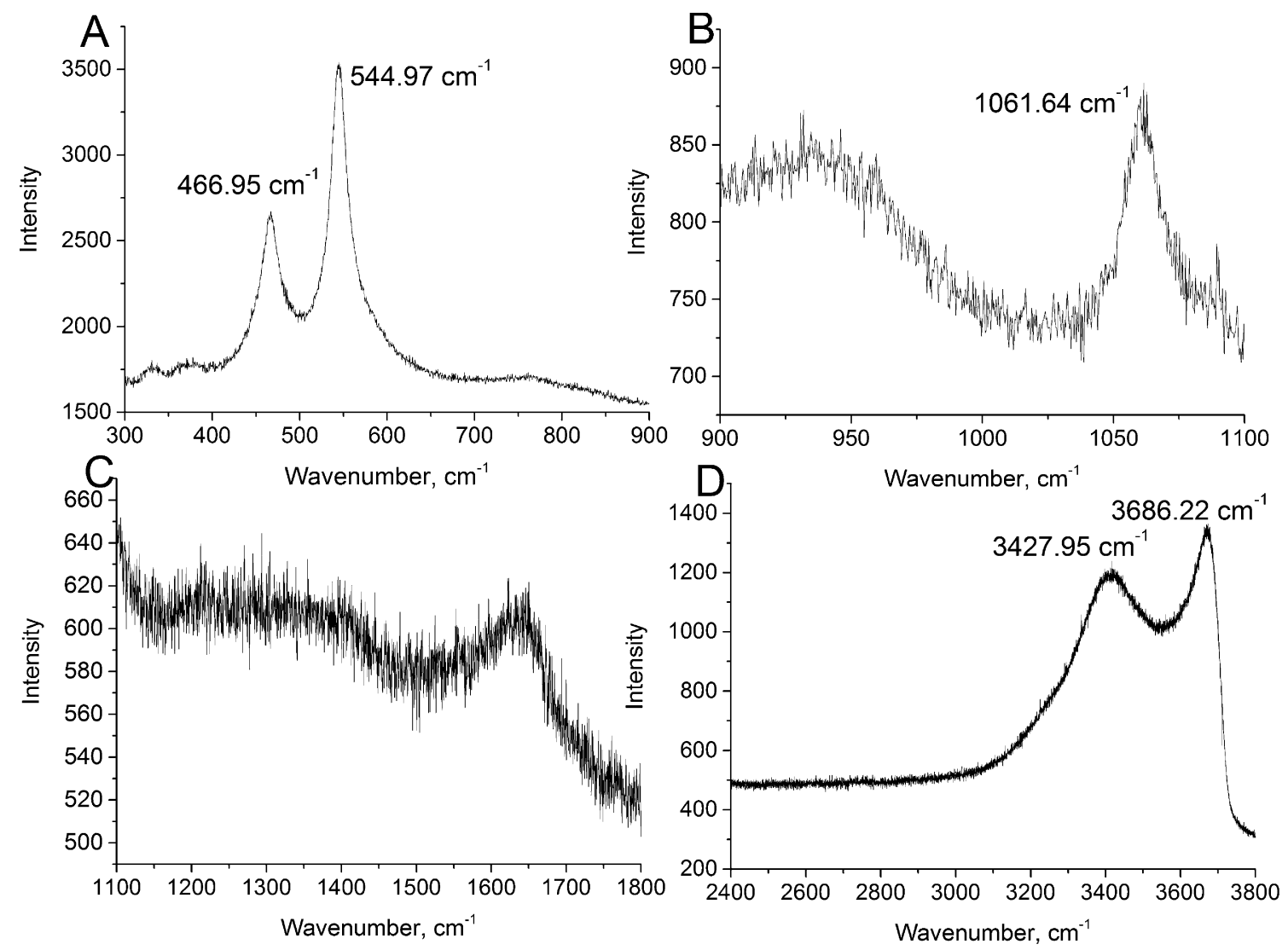

Fig. 4: Raman spectra of $\mathrm{Zr}$-containing LDH with $x \mathrm{Zr}_{\text {solid }} \approx 0.1$. A more detailed description of individual spectra is given in the text. 
or/and during the preparation of samples for Raman measurements. The band around $1060 \mathrm{~cm}^{-1}$ is also confirming the presence of $\mathrm{CO}_{3}{ }^{2-}$ and corresponds to interlayer carbonate anions associated with $\mathrm{Me}(\mathrm{OH})_{6}$ octahedral units in the brucite-like layers [32]. In the whole range of $\mathrm{Zr}$ content in synthesized hydrotalcite-like solids the position of this peak remains almost constant indicating no change in symmetry of carbonate anions. The large bands around $3450 \mathrm{~cm}^{-1}$ and $3700 \mathrm{~cm}^{-1}$ represent OH-stretching vibrations from $\mathrm{MeOH}$-groups as well as stretching vibrations of interlayer water molecules. Results of band component analyses demonstrated that the peak positions and intensities of all Raman bands are not correlating with the $\mathrm{Zr}$ content in precipitates.

Scanning electron microscopy demonstrated that the majority of synthesized solids were similar to typical LDHs "sand rose" aggregates. Energy dispersive X-ray analyses shown that in synthesized solids with $x \mathrm{Zr}_{\text {solid }}$ from 0 to 0.5 the distribution of $\mathrm{Mg}, \mathrm{Al}, \mathrm{Zr}, \mathrm{C}, \mathrm{O}$ and $\mathrm{Cl}$ components is generally homogeneous and obtained stoichiometric coefficients of precipitates are in good agreement with results of ICP-OES analyses. The chemical homogeneity of samples has been proved by numerous replications (up to 10) of EDX measurements on various regions of LDH grains.

\subsection{Estimation of the standard Gibbs energies and thermodynamic properties of synthesized Zr-containing LDHs}

Thermodynamic properties of synthesized $\mathrm{Zr}$-containing LDH solids have been estimated according to the scheme described in Section 2.7 and assuming the thermodynamic equilibrium between precipitates and aqueous solutions after synthesis experiments. This assumption was based on previous results [29] which clearly shown that the degree of oversaturation in liquids after co-precipitation experiments was negligible and, therefore, precipitated solids and corresponding aqueous solutions were at conditions close to thermodynamic equilibrium. On Figure 5 the calculated values of standard molar Gibbs free energies of solids are shown as a function of $\mathrm{Zr}$-content (i.e., $\mathrm{Zr} /(\mathrm{Zr}+\mathrm{Al})$ ratios in solids). Moreover, from this figure it is clear that the addition of only 0.1 units of zirconium into the hydrotalcite structure increases the value of standard Gibbs free energy significantly (approximately $100 \mathrm{~kJ} / \mathrm{mol}$ ). The reason of this increase has to be related with structural modifications originating from the $\mathrm{Zr}$-incorporation into pure Mg-Al-LDH composition. The obvious explanation of this major effect of zirconium may

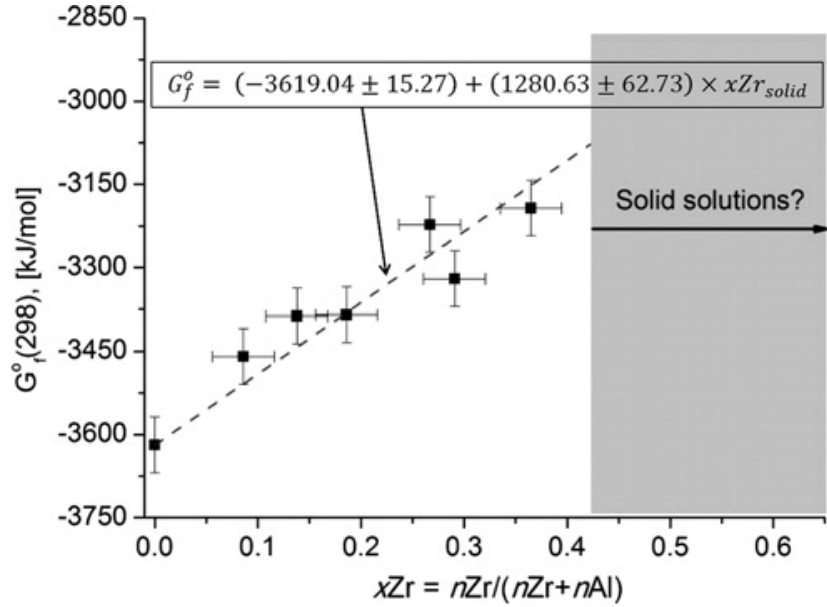

Fig. 5: Standard Gibbs free energies of "water-free" solids calculated as a function of the mole fraction of zirconium.

be that $\mathrm{Zr}$ occupies the interlayer space in hydrotalcite structure and, therefore, significantly disturbing the structural stability of LDHs. As mentioned in Section 3.2, in the present study we were not able to check this hypothesis by applying analytical and spectroscopic methods. Therefore, only theoretical thermodynamic considerations have been used. On the first step, the compositions of aqueous solutions after syntheses have been modeled by using GEM-Selektor code package as described before and predominant aqueous complexes of $\mathrm{Mg}, \mathrm{Al}$ and $\mathrm{Zr}$ were determined. Results of the modeling shown that at conditions of syntheses $\left(\mathrm{pH}=10.00 \pm 0.05, T=25-2{ }^{\circ} \mathrm{C}\right)$ the dissolved metals have to be mainly presented as $\mathrm{Mg}^{2+}$, $\mathrm{Al}(\mathrm{OH})_{4}^{-}$and $\mathrm{Zr}(\mathrm{OH})_{5}{ }^{-}$aqueous species. Thus, from this result we can suppose that $\mathrm{Zr}$ could play a role of "anionic" $\mathrm{Zr}(\mathrm{OH})_{5}{ }^{-}$constituent and it can be incorporated (at least partially) into the interlayer between brucite-like layers. The possible reaction of such incorporation of $\mathrm{Zr}$ into the pure $\mathrm{Mg}-\mathrm{Al}-\mathrm{LDH}$ is written as:

$$
\begin{aligned}
& \mathrm{Mg}_{3} \mathrm{Al}(\mathrm{OH})_{8} \mathrm{Cl}_{1(\mathrm{~s})}+\mathrm{Zr}(\mathrm{OH})_{5(\mathrm{aq})}^{-}=\mathrm{Mg}_{1} \mathrm{Zr}_{1}(\mathrm{OH})_{5} \mathrm{Cl}_{1(\mathrm{~s})} \\
& +\mathrm{Al}(\mathrm{OH})_{4(\mathrm{aq})}^{-}+2 \mathrm{Mg}_{(\mathrm{aq})}^{2+}+4 \mathrm{OH}_{(\mathrm{aq})}^{-},
\end{aligned}
$$

where $\mathrm{Mg}_{1} \mathrm{Zr}_{1}(\mathrm{OH})_{5} \mathrm{Cl}_{1}$ composition is corresponding to the "hypothetical" end-member according to discovered $\left[\mathrm{Mg}_{3-2 \mathrm{x}} \mathrm{Al}_{1-\mathrm{x}} \mathrm{Zr}_{\mathrm{x}}\right]$-stoichiometry $\left(x \mathrm{Zr}_{\text {solid }}=1\right)$. Thermodynamically the Reaction 2 seems to be reasonable: assuming the equilibrium (i.e., $\Delta_{\mathrm{r}} G=0$ ) and by using known values (see Table 3 ) of the molar Gibbs free energies of $\mathrm{Mg}_{3} \mathrm{Al}_{1}(\mathrm{OH})_{8} \mathrm{Cl}_{1}, \mathrm{Zr}(\mathrm{OH})_{5}{ }^{-}, \mathrm{Al}(\mathrm{OH})_{4}^{-}, \mathrm{Mg}^{2+}, \mathrm{OH}^{-}$, the molar Gibbs free energy of formation of $\mathrm{Mg}_{1} \mathrm{Zr}_{1}(\mathrm{OH})_{5} \mathrm{Cl}_{1}$ 
Table 3: Standard molar Gibbs free energies used in thermodynamic calculations.

\begin{tabular}{lrr}
\hline Substance/Complex & $\boldsymbol{G}_{\boldsymbol{f}}^{\boldsymbol{o}}$, [kJ/mol] & Reference \\
\hline $\mathrm{Mg}_{3} \mathrm{Al}_{1}(\mathrm{OH})_{8} \mathrm{Cl}_{1(\mathrm{~s})}$ & $-3619.04 \pm 15.27$ & $(1)$ \\
$\mathrm{Zr}(\mathrm{OH})_{5(\mathrm{aq})}^{-}$ & -1177.82 & $(2)$ \\
$\mathrm{Al}^{-}(\mathrm{OH})_{4}^{-}(\mathrm{aq})$ & -827.48 & $(2)$ \\
$\mathrm{Mg}_{(\text {(aq) }}^{2+}$ & -453.99 & $(2)$ \\
$\mathrm{OH}_{\text {(aq) }}^{-}$ & -157.27 & $(2)$ \\
\hline
\end{tabular}

(1) - Rozov et al., 2013; (2) - Hummel et al., 2002.

stoichiometry composition will correspond to:

$$
\begin{aligned}
& G_{\mathrm{f}}^{\circ}\left[\mathrm{Mg}_{1} \mathrm{Zr}_{1}(\mathrm{OH})_{5} \mathrm{Cl}_{1}\right]_{(\mathrm{s})}=G_{\mathrm{f}}^{\circ}\left[\mathrm{Mg}_{3} \mathrm{Al}_{1}(\mathrm{OH})_{8} \mathrm{Cl}_{(\mathrm{s})}\right. \\
& +G_{\mathrm{f}}^{\circ}\left[\mathrm{Zr}(\mathrm{OH})_{5}^{-}\right]_{(\mathrm{aq})}-G_{\mathrm{f}}^{\circ}\left[\mathrm{Al}(\mathrm{OH})_{4}^{-}\right]_{(\mathrm{aq})}-2 \mathrm{G}_{\mathrm{f}}^{\circ}\left[\mathrm{Mg}^{2+}\right]_{(\mathrm{aq})} \\
& -4 G_{\mathrm{f}}^{\circ}\left[\mathrm{OH}^{-}\right]_{(\mathrm{aq})}=-2432.33 \pm 15.27 \mathrm{~kJ} / \mathrm{mol}
\end{aligned}
$$

This value $(-2432.33 \pm 15.27 \mathrm{~kJ} / \mathrm{mol})$ is in a good agreement with the number $(-2338.41 \pm 64.56 \mathrm{~kJ} / \mathrm{mol})$ obtained from the linear approximation $G_{f}^{0}=(-3619.04 \pm 15.72)+$ $(1280.63 \pm 62.73) \times x \mathrm{Zr}_{\text {solid }}$ shown on Figure 5. This fact may support additionally the proposed substitution mechanism.

\section{Conclusions}

The aim of the present work was to investigate the possibility of the isostructural substitution of tetravalent cations (particularly, zirconium) into the hydrotalcite-like solids by using results of co-precipitation experiments carried out at ambient conditions $\left(T=25 \pm 2{ }^{\circ} \mathrm{C}, P=1 \mathrm{bar}\right.$ ), applying various characterization techniques and considering results of thermodynamic modeling. The scheme (see Figure 6) has been constructed in order to reflect clearly the sequence of experimental observations and corresponding interpretations. This diagram helped to formulate the provisional scheme $\mathrm{Zr}$ incorporation into the hydrotalcite structure.

Firstly, results of PXRD technique demonstrated that hydrotalcite-like solids with variable $\mathrm{Zr}$-content $(0<$ $\left.x \mathrm{Zr}_{\text {solid }} \leq 0.5\right)$ have been successfully synthesized. Nevertheless, in precipitates with $x \mathrm{Zr}_{\text {solid }}>0.5$ the additional Xray diffraction reflexes attributed to brucite were observed.

Results of chemical analyses demonstrated that the $\mathrm{Mg} /(\mathrm{Al}+\mathrm{Zr})$ cationic ratios in pure $\mathrm{Zr}$-bearing hydrotalcites are significantly reducing (from 3 to 2 ) with the increase of $\mathrm{Zr}$-mole fraction $(\mathrm{Zr} /(\mathrm{Zr}+\mathrm{Al}))$ in spite of the constant $\mathrm{Mg} /(\mathrm{Al}+\mathrm{Zr})=3.0 \pm 0.1$ ratio in initial metalcontaining solutions used for experiments. These stoichiometric variations allowed summarizing the composition of cationic part of brucite-like layers as $\left[\mathrm{Mg}_{3-2 \mathrm{x}} \mathrm{Al}_{1-\mathrm{x}} \mathrm{Zr}_{\mathrm{x}}\right]$. Considering $x=0$ and $x=1$ for this stoichiometry it is obviously to conclude that the incorporation of $1 \mathrm{Zr}$ containing specie results in the removal of $2 \mathrm{Mg}$ - and $1 \mathrm{Al}$-containing species from pure $\mathrm{Mg}$-Al hydrotalcite endmember. Nevertheless, from this fact it is not possible to specify the structural position of incorporated $\mathrm{Zr}$. Therefore, we used results of PXRD technique and observed that $a_{0}=b_{0}$ unit-cell parameters of pure $\mathrm{Zr}$-containing LDHs are related with those compositional variations

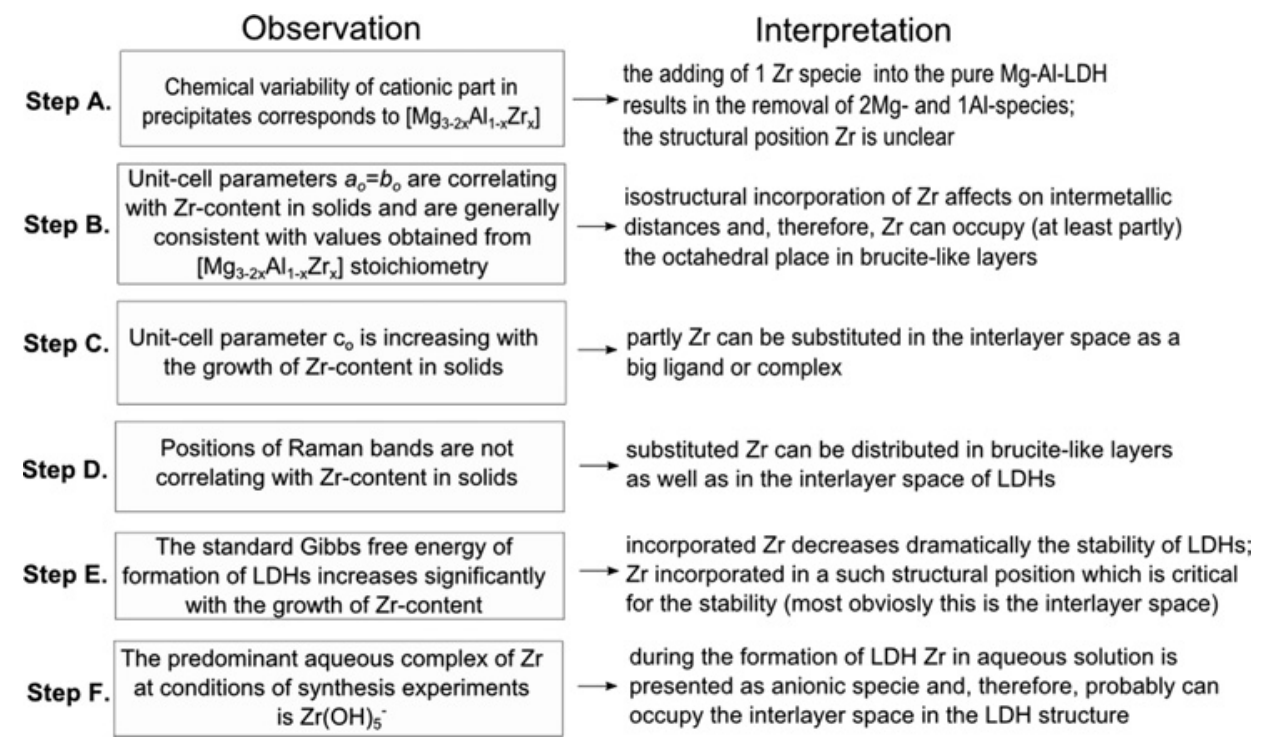

Fig. 6: Logic chart representing the sequence of experimental observations and corresponding interpretations. 
$\left(x \mathrm{Zr}_{\text {solid }}\right.$ and $\mathrm{Mg} /(\mathrm{Al}+\mathrm{Zr})$ ratios $)$. Measured $a_{0}=b_{0}$ distances were compared with values obtained from theoretical $\left[\mathrm{Mg}_{3-2 \mathrm{x}} \mathrm{Al}_{1-\mathrm{x}} \mathrm{Zr}_{\mathrm{x}}\right]$-stoichiometry which corresponds to regular octahedral layers and the general coincidence between them has been found. This fact can indicate that $\mathrm{Zr}$ incorporation affects on intermetallic distances in brucitelike layers and, thus, $\mathrm{Zr}$ can be substituted in the octahedral positions of brucite-like layers. On the other hand, unit-cell parameter $c_{0}$ represents the interlayer distance between brucite-like layers is also correlating with $\mathrm{Zr}$ content in LDHs. Therefore, it is possible to suppose that some part of $\mathrm{Zr}$ can be substituted in the interlayer space.

Results of Raman spectroscopic measurements demonstrated that synthesized LDHs have a very strong affinity to carbonate-anions: in all precipitates the bands around $546 \mathrm{~cm}^{-1}$ (attributed to the interlayer carbonate and water molecules), $1060 \mathrm{~cm}^{-1}$ (interaction of carbonate with $\mathrm{Me}(\mathrm{OH})_{6}$ octahedral units) were detected. Raman bands typical for hydrotalcite-like solids have been detected in regions aroung $467 \mathrm{~cm}^{-1}$ (assigned to the Me-O-Me linkage bonding), 3450 and $3700 \mathrm{~cm}^{-1}$ $(\mathrm{OH}$-stretching vibrations from $\mathrm{MeOH}$-groups of brucitelike layers as well as stretching vibrations of interlayer water molecules). The dependence of positions of all Raman bands on $\mathrm{Zr}$-content was not observed indicating implicitly that Zr-species can occupy simultaneously structural positions in brucite-like layers and in interlayers.

In order to corroborate the hypothesis that $\mathrm{Zr}$ is partly incorporated in the interlayer space of LDH structure, the thermodynamic modeling with GEMS-Selektor code v.3. has been applied. The standard Gibbs free energies of formation for pure precipitates have been estimated assuming the thermodynamic equilibrium between solids and supernatant solutions after experiments. The observed correlation between the standard Gibbs free energies and $\mathrm{Zr}$-content in these solids demonstrates that the addition of small traces of zirconium decreases significantly the stability of synthesized solids. For instance, the addition of only 0.1 molar unit of $\mathrm{Zr}$-mole fraction increases the standard Gibbs free energy by approximately $100 \mathrm{~kJ} /$ moles. Furthermore, results of modeling demonstrated that at conditions of co-precipitation experiments $\mathrm{Mg}, \mathrm{Al}$ and $\mathrm{Zr}$ in aqueous solution are presented as $\mathrm{Mg}^{2+}, \mathrm{Al}(\mathrm{OH})_{4}^{-}$and $\mathrm{Zr}(\mathrm{OH})_{5}{ }^{-}$complexes. Therefore, it is likely that zirconium is substituted into the hydrotalcite structure as negative-charged "anionic" compound and, consequently, it can be localized in the interlayer space. In such case the significant decrease of hydrotalcite stability with addition of zirconium is reasonably explainable. The reaction of $\mathrm{Zr}$-substitution will be written as:
$\mathrm{Mg}_{3} \mathrm{Al}(\mathrm{OH})_{8} \mathrm{Cl}_{1(\mathrm{~s})}+\mathrm{Zr}(\mathrm{OH})_{5(\mathrm{aq})}^{-}=\mathrm{Mg}_{1} \mathrm{Zr}_{1}(\mathrm{OH})_{5} \mathrm{Cl}_{1(\mathrm{~s})}+$ $\mathrm{Al}(\mathrm{OH})_{4(\mathrm{aq})}^{-}+2 \mathrm{Mg}_{(\mathrm{aq})}^{2+}+4 \mathrm{OH}_{(\mathrm{aq})}^{-}$. The value of the standard Gibbs free energy of formation for $\mathrm{Mg}_{1} \mathrm{Zr}_{1}(\mathrm{OH})_{5} \mathrm{Cl}_{1}$ composition has been obtained from this reaction and is in the excellent agreement with estimate calculated from the linear approximation presented on Figure 5.

Finally, the statement which is formulating the scheme of Zr-incorporation into the hydrotalcite structure is: "zirconium can be structurally incorporated into the LDH. At that, zirconium can occupy two structural sites in hydrotalcite-like solids: in octahedral brucite-like layers and in the interlayer space as $\mathrm{Zr}(\mathrm{OH})_{5}{ }^{-}$ligands. This situation leads to very significant decrease of stability of LDHs even if very small $\mathrm{Zr}$-content in the LDH is included. The adding of higher amounts of $\mathrm{Zr}$ into the hydrotalcite system $(\mathrm{Zr} /(\mathrm{Zr}+\mathrm{Al}) \geq 0.5)$ finally prevents the formation of sequences of brucite-like layers. Therefore, the fine-crystalline brucite is detected by PXRD method as secondary phase in precipitates with $x \mathrm{Zr}_{\text {solid }} \geq 0.5$ ". Further spectroscopic investigations (for instance, EXAFS analyses) will be applied to specify the coordination environment of zirconium in the LDH structure.

Acknowledgement: We thank Dr. Hartmut Schlenz, Jakob Dellen - for their help with PXRD and Raman spectroscopy; Dr. Andrey Bukaemskiy, Dr. Martina Klinkenberg - for their support with SEM/EDX measurements; Zaina Paparigas, Katharina Dahmen, Gabriel Kaiser - for support in the lab. The study has been funded in part by Bundesministerium für Bildung und Forschung through grant 02NUK019C.

\section{References}

1. Aramendia, M. A., Borau, V., Jimenez, U., Marinas, J. M., Ruiz, J. R., Urbano, F. J.: Comparative study of $\mathrm{Mg} / \mathrm{M}(\mathrm{III})(\mathrm{M}=\mathrm{Al}, \mathrm{Ga}$, In) layered double hydroxides obtained by coprecipitation and the sol-gel method. Journal of Solid State Chemistry 168, 156161 (2002).

2. Boclair, J. W., Braterman, P. S., Jiang, J. P., Lou, S. W., Yarberry, F.: Layered double hydroxide stability. 2. Formation of $\mathrm{Cr}$ (III)containing layered double hydroxides directly from solution. Chemistry of Materials 11, 303-307 (1999).

3. Carteret, C., Gregoire, B., Ruby, C.: Tunable composition of NiII-Al-III and Ni-II-Fe-III layered hydroxides within a wide range of layer charge. Solid State Science 13, 146-150. (2011)

4. Curtius, H., Paparigas, Z., Kaiser, G.: Sorption of selenium on $\mathrm{Mg}-\mathrm{Al}$ and $\mathrm{Mg}-\mathrm{Al}-\mathrm{Eu}$ layered double hydroxides. Radiochimica Acta 96, 651-655 (2008).

5. Curtius, H., Ufer, K., Dardenne, K.: Preparation and characterization of $\mathrm{Zr}$-IV-containing $\mathrm{Mg}$-Al-Cl layered double hydroxide. Radiochimica Acta 97, 423-428 (2009). 
6. Rousselot, I., Taviot-Gueho, C., Leroux, F., Leone, P., Palvadeau, P., Besse, J. P.: Insights on the structural chemistry of hydrocalumite and hydrotalcite-like materials: Investigation of the series $\mathrm{Ca}_{2} \mathrm{M}^{3+}(\mathrm{OH})_{6} \mathrm{Cl} \cdot 2 \mathrm{H}_{2} \mathrm{O}\left(\mathrm{M}^{3+}: \mathrm{Al}^{3+}, \mathrm{Ga}^{3+}, \mathrm{Fe}^{3+}\right.$, and $\left.\mathrm{Sc}^{3+}\right)$ by $\mathrm{X}$-ray powder diffraction. Journal of Solid State Chemistry 167, 137-144 (2002).

7. Rozov, K., Curtius, H., Neumann, A., Bosbach, D.: Synthesis, characterization and stability properties of $\mathrm{Cl}$-bearing hydrotalcite-pyroaurite solids. Radiochimica Acta 101, 101-109 (2013).

8. Ulibarri, M. A., Cornejo, J., Hernandez, M. J.: Effects of hydrothermal treatment on textural properties of $\mathrm{Al}_{2} \mathrm{Li}(\mathrm{OH})_{6} \mathrm{CO}_{3} \cdot \mathrm{nH}_{2} \mathrm{O}$. Journal of Material Science 22, 11681172 (1987).

9. Wang, J. D., Serrette, G., Tian, Y., Clearfield, A.: Synthetic and catalytic studies of inorganically pillared and organically pillared layered double hydroxides. Applied Clay Science 10, 103-115 (1995).

10. Allada, R. K., Navrotsky, A., Boerio-Goates, J.: Thermochemistry of hydrotalcite-like phases in the $\mathrm{MgO}-\mathrm{Al}_{2} \mathrm{O}_{3}-\mathrm{CoO}_{2}-\mathrm{H}_{2} \mathrm{O}$ system: a determination of enthalpy, entropy and free energy. American Mineralogist 90, 329-335 (2005).

11. Brindley, G. W., Kikkawa, S.: Thermal-Behavior of Hydrotalcite and of Anion-Exchanged Forms of Hydrotalcite. Clays and Clay Minerals 28, 87-91 (1980).

12. Carlino, S.: The intercalation of carboxylic acids into layered double hydroxides: A critical evaluation and review of the different methods. Solid State Ionics 98, 73-84 (1997).

13. Carrado, K. A., Kostapapas, A., Suib, S. L.: Layered Double Hydroxides (LDHs), Solid State Ionics 26, 77-86 (1988).

14. Chibwe, K., Jones, W.: Intercalation of Organic and Inorganic Anions into Layered Double Hydroxides, Journal of Chemical Society 926-927 (1989).

15. Chisem, I. C., Jones, W.: Ion-Exchange Properties of Lithium Aluminum Layered Double Hydroxides. Journal of Materials Chemistry 4, 1737-1744 (1994).

16. Miyata, S., Kumura, T.: Synthesis of New Hydrotalcite-Like Compounds and Their Physicochemical Properties. Chemistry Letters 843-848 (1973).

17. Newman, S. P., Jones, W.: Synthesis, characterization and applications of layered double hydroxides containing organic guests. New Journal of Chemistry 22, 105-115 (1998).

18. Hummel, W.: Nagra/PSI Chemical Thermodynamic Data Base 01/01. Universal-Publishers, 2002.

19. Das, N., Samal, A.: Synthesis, characterisation and rehydration behaviour of titanium(IV) containing hydrotalcite like compounds. Microporous and Mesoporous Materials 72, 219-225 (2004).

20. Tichit, D., Das, N., Coq, B., Durand, R.: Preparation of Zrcontaining layered double hydroxides and characterization of the acido-basic properties of their mixed oxides. Chemistry of Materials 14, 1530-1538 (2002).
21. Velu, S., Ramaswamy, V., Ramani, A., Chanda, B. M., Sivasanker, S.: New hydrotalcite-like anionic clays containing $\mathrm{Zr}^{4+}$ in the layers. Chemical Communications 2107-2108 (1997).

22. Velu, S., Sabde, D. P., Shah, N., Sivasanker, S.: New hydrotalcite-like anionic clays containing $\mathrm{Zr}^{4+}$ in the layers: Synthesis and physicochemical properties. Chemistry of Materials 10, 3451-3458 (1998).

23. Velu, S., Suzuki, K., Kapoor, M. P., Tomura, S., Ohashi, F., Osaki T.: Effect of $\mathrm{Sn}$ incorporation on the thermal transformation and reducibility of $\mathrm{M}$ (II)Al-layered double hydroxides $\mathrm{M}(\mathrm{II})=\mathrm{Ni}$ or Co. Chemistry of Materials 12, 719-730 (2000).

24. Velu, S., Suzuki, K., Okazaki, M., Osaki, T., Tomura, S., Ohashi, F.: Synthesis of new Sn-incorporated layered double hydroxides and their thermal evolution to mixed oxides. Chemistry of Materials 11, 2163-2172 (1999).

25. Intissar, M., Jumas, J. C., Besse, J. P., Leroux, F.: Reinvestigation of the layered double hydroxide containing tetravalent cations: Unambiguous response provided by XAS and Mossbauer spectroscopies. Chemistry of Materials 15, 4625-4632 (2003).

26. Kulik, D. A., Wagner, T., Dmytrieva, S. V., Kosakowski, G., Hingerl, F. F., Chudnenko, K. V., Berner, U. R.: GEM-Selektor geochemical modeling package: revised algorithm and GEMS3K numerical kernel for coupled simulation codes. Computational Geosciences 17, 1-24 (2013).

27. Wagner, T., Kulik, D. A., Hingerl, F. F., Dmytrievava, S. V.: GEMSelektor geochemical modeling package: TSolMod library and data interface for multicomponent phase models. Canadian Mineralogist 50, 1173-1195 (2012).

28. Rozov K., Berner U., Taviot-Gueho C., Leroux F., Renaudin G., Kulik D., Diamond L. W.: Synthesis and chracterization of the LDH hydrotalcite-pyroaurite solid solution series. Cement and Concrete Research 40, 1248-1254 (2010).

29. Rozov, K. B., Berner, U., Kulik, D. A., Diamond, L. W.: Solubility and thermodynamic properties of carbonate-bearing hydrotalcite-pyroaurite solid solutions with a $3: 1 \mathrm{Mg} /(\mathrm{Al}+\mathrm{Fe})$ mole ratio. Clays and Clay Minerals 59, 215-232 (2011).

30. Davies, C. W.: Ion association, Butterworths, Washington, 1962.

31. Shannon, R.: Revised effective ionic radii and systematic studies of interatomic distances in halides and chalcogenides. Acta Crystallographica Section A 32, 751-767 (1976).

32. Frost, R. L., Reddy, B. J.: Thermo-Raman spectroscopic study of the natural layered double hydroxide manasseite. Spectrochimica Acta Part A-Molecular and Biomolecular Spectroscopy 65, 553-559 (2006).

33. Palmer, S. J., Frost, R. L.: The Effect of Synthesis Temperature on the Formation of Hydrotalcites in Bayer Liquor: A Vibrational Spectroscopic Analysis. Applied Spectroscopy 63, 748-752 (2009). 